\title{
Cytopathological observations on renal tubule epithelium cells in common carp Cyprinus carpio under Trypanoplasma borreli (Protozoa: Kinetoplastida) infection
}

\author{
Sabine Rudat ${ }^{1}$, Dieter Steinhagen ${ }^{1, *}$, Udo Hetzel ${ }^{2}$, Wolfgang Drommer ${ }^{2}$, \\ Wolfgang Körting ${ }^{1}$
}

${ }^{1}$ Fish Diseases Research Unit and ${ }^{2}$ Pathology Department, School of Veterinary Medicine, Bünteweg 17, 30559 Hannover, Germany

\begin{abstract}
Cytological alterations in renal tubule epithelium cells of carp Cyprinus carpio infected with the blood flagellate Trypanoplasma borreli Laveran \& Mesnil, 1901 were investigated during the course of a laboratory infection of a highly susceptible carp line. With the development of the parasitaemia, a hyperplasia of the interstitial renal tissue was induced, which resulted in a tubulus necrosis Cytological changes were already seen in tubulus epithelium cells on Day 7 post injection (PI) of the parasite. The basilar invaginations of the cells fragmented and a swelling of mitochondria was noted With increasing parasitaemia, on Days 14 and 21 PI, these changes progressed up to the loss of the basilar invagination and high amplitude swellings of mitochondria and deterioration of their internal membrane structures. Cells of the distal tubule segment reacted earlier and more rapidly than cells of the proximal tubule. The cytological alterations suggested a loss of function of the epithelum cells, which most likely resulted in impaired ionic and osmotic regulation of $T$. borreli-infected fishes. Our findings indicate that in response to the proliferation of the interstitial renal tissue cell structures of the renal tubule cells are altered quickly and in a progressive manner.
\end{abstract}

KEY WORDS: Trypanoplasma borreli $\cdot$ Blood flagellates $\cdot$ Cytopathology $\cdot$ Tubular necrosis $\cdot$ Cyprinus carpio

\section{INTRODUCTION}

Trypanoplasma borreli (Kinetoplastida: Cryptobiidae) is a blood flagellate of European cyprinids (Lom \& Dykova 1992), of which some strains are pathogenic and cause mortality in goldfish Carassius auratus, cf. Lom \& Dykova 1992, and carp Cyprinus carpio, cf. Wiegertjes et al. 1995. In nature the parasite is transmitted by the fish-biting leeches Piscicola geometra and Hemiclepsis marginata (cf. Keysselitz 1906). In the laboratory infections can be induced by injection of infected blood into the muscle or body cavity of recipient carp or goldfish (Lom 1979, Steinhagen et al. 1989). Steinhagen et al. (1989) established a cloned

·Corresponding author. E-mail: dstein@fisch.tiho-hannover.de strain from this parasite and developed a laboratory model to study the host parasite relationship. Susceptible carp developed anaemia, gill pallor, splenomegaly and ascitis with increasing parasitaemia and subsequently died from the infection (Lom et al. 1986, Wiegertjes et al. 1995, Bunnajirakul et al. 2000). In heavily infected carp histopathological lesions were found in most organs, with necrosis of renal tubules, endothelial hyperplasia, congestion of liver sinusoids, and accumualtion of erythrocytes in the spleen. The capillaries of liver, gills and heart were filled with inflammatory cells (Lom \& Dykova 1992, Bunnajirakul et al. 2000). In the interstitial tissue of the kidney mononuclear cells proliferated rapidly, which resulted in a marked increase of the interstitial tissue and a progressive depression and deterioration of renal 
tubules (Bunnajirakul et al. 2000). To monitor cytological changes of epithelium cells from proximal and distal tubule sections in $T$. borreli-infected carp we performed the present study, concentrated on TEM observations, which were not included in the previous communication by Bunnajirakul et al. (2000). In this study we obtained data on the ultrastructural level on the induction of a tubulus necrosis in a freshwater teleost which is associated with a hyperplasia of the haematopoietic tissue in the kidney.

\section{MATERIALS AND METHODS}

Fish. Parasite-free carp from a single crossing (E20 $\times$ R8, Wageningen Agricultural University, The Netherlands) were used throughout the study. The female (E20) originated from an outbred female, which was reproduced gynogenetically. This isogenic female was crossed with an outbred male of Hungarian origin (Wiegertjes et al. 1995). The carp were propagated and raised under parasite-free conditions in closed laboratory facilites in fiberglass tanks filled with filtered recirculating tap water at $20 \pm 2^{\circ} \mathrm{C}$. The fish raising facilities excluded a previous infection with the parasite, and the blood of some fish from the stock were checked for the presence of blood parasites on a regular basis. The fish were fed initially with Artemia salina nauplii, then the feeding regime was switched to commercial carp chow (Alma Feed, Kempten, Germany) at a ratio of $2 \%$ of the body weight daily. The carp used in the experiments had a body weight of 50 to $60 \mathrm{~g}$ and were approx. 12 mo old.

Parasite infection and histology. For infection experiments, Trypanoplasma borreli from a cloned strain were used (Steinhagen et al. 1989). The parasites were maintained in the laboratory by syringe passage through parasite-free carp, which were found to be highly susceptible to the infection (Bunnajirakul et al. 2000). For the experiments in the current study, 20 carp were infected by intramuscular injection of $50 \mu l$ phosphate buffered salt solution (PBS) which contained 5000 viable $T$. borreli and then kept at $20 \pm 2^{\circ} \mathrm{C}$. At 7 . 14 , and $21 \mathrm{~d}$ post injection (PI), 4 carp were anaesthetized by immersion into tricaine $\left(0.15 \mathrm{gl}^{-1}\right)$, chilled on ice, killed by severing the spinal cord, placed on an ice-cold polyethylene plate and then necropsied. Small pieces of kidney tissue were collected immediately from the right portion of the trunk kidney and fixed with phosphate buffered formalin (4\% v/v, $\mathrm{pH} 7.2)$ for light microscopy and with $2.5 \%$ glutaraldehyde in $0.1 \mathrm{M}$ cacodylate buffer at $\mathrm{pH} 7.2$ for transmission electron microscopy (TEM). For controls, tissue samples were taken from 4 uninfected control carp and fixed correspondingly. Additionally, blood samples were taken from all carp (infected and controls) for determination of the parasitaemia by means of a haematocytometer.

For light microscopic observations, the tissue was dehydrated in a series of graded ethanols, placed into chloroform and then infiltrated with paraffin wax. From paraffin blocks, $5 \mu \mathrm{m}$ thick sections were cut, stained with haematoxylin and eosin (Romeis 1989) and observed with a Zeiss photomicroscope (Zeiss, Oberkochem, Germany). For TEM glutaraldehyde-fixed tissue samples were postfixed with $1 \%$ osmium tetroxide in $0.1 \mathrm{M}$ cacodylate buffer $(\mathrm{pH} \mathrm{7.2)}$ for $1 \mathrm{~h}$, rinsed with the same buffer, dehydrated in a series of graded ethanols and embedded in epoxy resin according to standard procedures (Hayat 1989). From the blocks semi-thin sections were cut, stained with $0.25 \%$ toluidine blue and observed with a Zeiss photomicroscope. Thin sections (approx. $70 \mathrm{~nm}$ ) were cut, stained with uranyl acetate and lead citrate (Hayat 1989) and observed with a Zeiss EM $10 \mathrm{C}$ electron microscope. Micrographs were taken on x-ray films (Agfa Gevaert, Leverkusen, Germany).

\section{RESULTS}

\section{Parasite development}

All carp injected with Trypanoplasma borreli developed a parasitaemia. At Day 7 PI, 3000 (SD 1700) $T$. borreli ml-1 blood were counted, on Day 14 PI, 21800 (SD 14600), and on Day 21 PI 1160000 (SD 74 800) flagellates $\mathrm{ml}^{-1}$ blood. On Days 23 and $24 \mathrm{PI}, 8$ carp died with signs of anaemia, abdominal distension and exophthalmus. The blood of these carp harboured high numbers of flagellates.

\section{Histo- and cytopathological observations on renal tubule epithelial cells}

On sections from kidney samples taken at the beginning of the parasitaemia on Days 7 and 14 PI, a slight increase in the proliferation of the interstitial lymphoid tissue could be seen with the light microscope. The tubulus epithelial cells appeared unchanged. When observed with TEM, the cells from the proximal tubule exhibited cell structures which were also seen in uninfected control fish: the apical pole was covered by a brush border with a glycocalyx; they contained numerous vacuoles, a central nucleus and basilar invaginations which extended from the basal pole of the cell up to the nuclear region. These invaginations were lined by numerous mitochondria (Fig. 1). In some of the cells from the infected carp a fragmentation of the basilar in- 


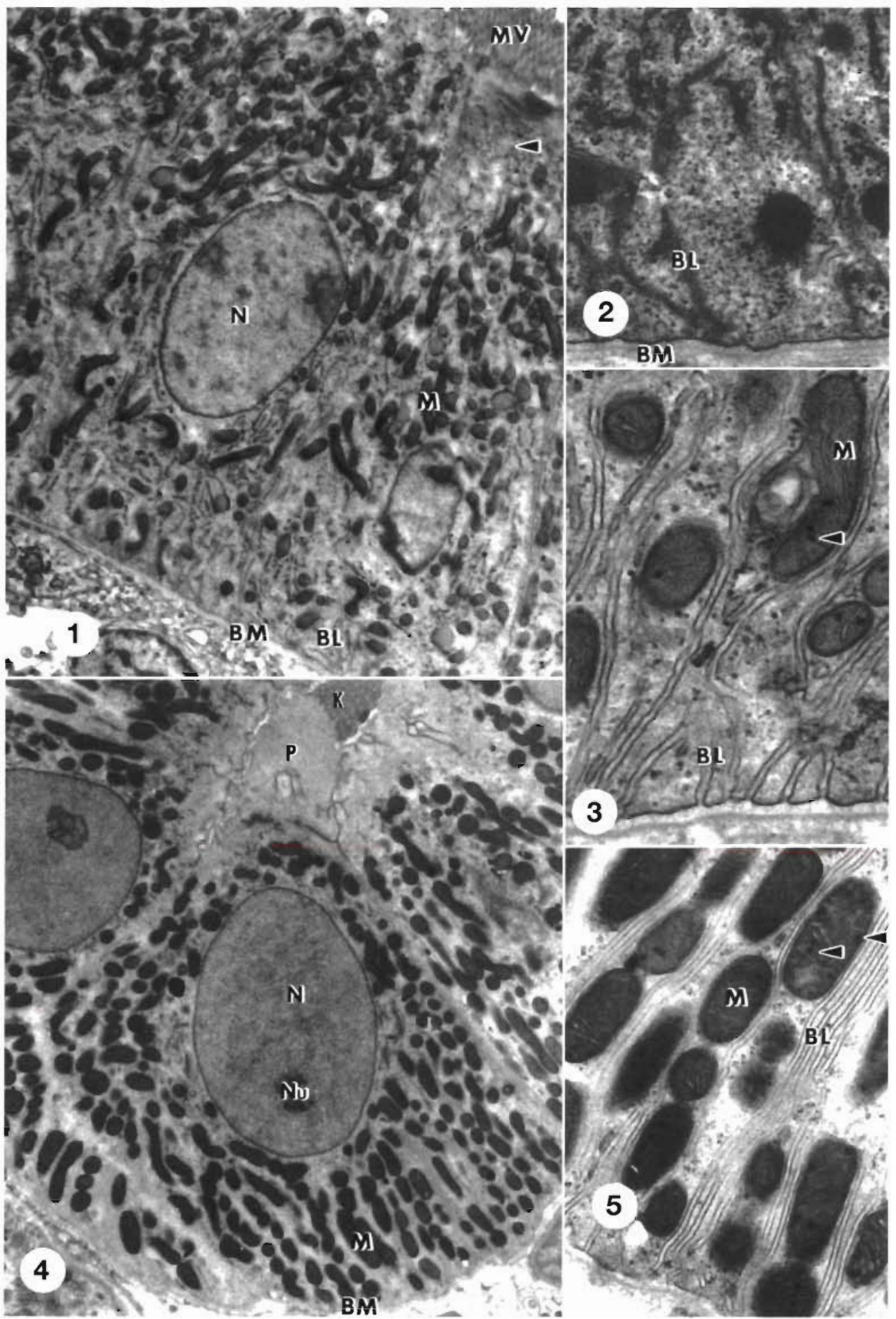

Figs. 1 to 5. Figs. 1 to 3. Epithelium cells from the proximal renal tubule of carp. Fig. 1. Epithelium cell from uninfected control carp. (TEM, ×5500). Fig. 2. Trypanoplasma borreli-infected carp $7 \mathrm{~d}$ PI. In the basal region of proximal tubule cells basilar invaginations (BL) fragmented and were filled with material of increased electron density (TEM, $\times 28000$ ). Fig. 3. Basal region of a proximal tubule cell from an uninfected carp. Arrowhead indicates mitochondrial granules (TEM, $\times 34400$ ). Fig. 4. Epithelium cells from the distal renal tubule of an uninfected carp (TEM, $\times 5500$ ). Fig. 5. Basal region of the cell with numerous basilar invaginations $(\mathrm{BL})$, which are lined with mitochondria (M). In the mitochondrial matrix granules are visible (arrow heads, TEM, $\times 22000$ ) BM: basal lamina; BL: basilar invaginations of the cell membrane; $\mathrm{M}$ : mitochondrium; $\mathrm{MV}$ : microvilli; $\mathrm{N}$; nucleus; Nu: nucleolus; P: apical protrusion of the cell; K: kinocilia 


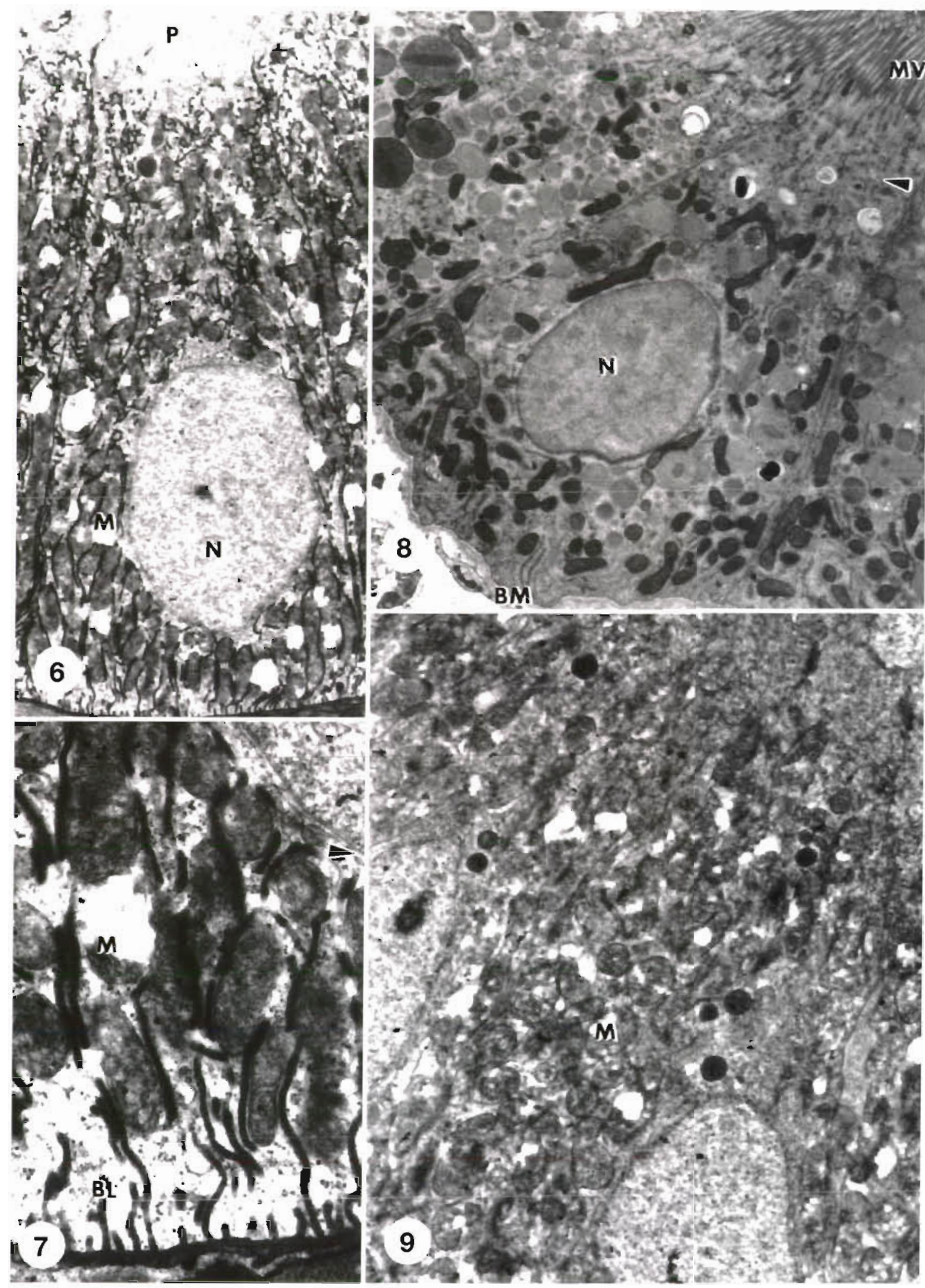

Figs. 6 to 9. Epithelium of the distal renal tubule in Trypanoplasma borreli-infected carp. Fig. 6. Epithelium cell at $7 \mathrm{~d}$ PI. The cell contains numerous mitochondria which show a prominent swelling (TEM, $\times 5800)$. Fig. 7 . Basal region of an epithelium cell at $7 \mathrm{~d}$ PI. The fragmentation of basilar infoldings and a prominent swelling of mitochondria is seen. The nuclear envelope (arrowhead) is still intact (TEM, $\times 23000$ ). Figs. 8 \& 9. Epithelium cells from the kidney of $T$. borreli-infected carp, $14 \mathrm{~d}$ PI. Fig. 8 . Proximal tubule cell: the cell appears swollen, the organelles are slightly dislocated. In the apical region, tubular invaginations are seen (arrowhead). (TEM, $\times 5800$ ). Fig. 9. Distal tubule cell: in the cell mitochondria are swollen, the cell appears to be filled with holes (TEM, ×5800). BM: basal lamind; BL: basilar infoldings of the plasma membrane; M: mitochondrium; MV: microvilli; N: nucleus; P: apical protrusion 
vaginations was seen at higher magnification (Fig. 2). This fragmentation was absent in cells from uninfected control carp (Fig. 3). The fragmented invaginations appeared to contain more condensed material when compared to cells from control fishes (compare Fig. 2 [infected] \& Fig. 3 [control]).

Cells from the distal tubulus possessed an apical protrusion and contained a central nucleus, elaborated endoplasmic reticulum and numerous basilar invaginations which were lined by high numbers of mitochondria (Figs, $4 \& 5$ ). In these cells a fragmention and degeneration of the plasma membrane of the basilar invaginations was also seen by Day 7 PI (Figs. 6 \& 7). When compared to cells from the proximal tubule this process appeared to be more pronounced in cells from the distal tubule. In some cells from the distal tubule the mitochondria seemed to be affected and showed a slight swelling when compared to cells from uninfected carp (compare Figs. $5 \& 7$ )

At Day 14 PI, when tissue samples were observed with TEM, the fragmentation of the basilar invaginations had progressed in epithelial cells from the proximal tubule. At this stage of parasitaemia, about $30 \%$ of the cells contained swollen mitochondria with expanded intercristal spaces, which caused a dislocation of organelles (compare Figs. $1 \& 8$ ). In the distal tubule, most of the epithelial cells showed a fragmentation of basilar infoldings, the mitochondria were of swollen, pale and edematous appearance. At low magnification cells appeared to be filled with holes (Fig. 9).

At Day 21 PI, the blood of the carp contained high numbers of trypanoplasms. The proliferation of interstitial cells had progressed massively, tubulus epithelial cells degenerated and tubuli atrophied (Fig. 10). In this stage of the parasitaemia numerous cells from the proximal tubule appeared to be filled with holes (Fig. 11), which resulted from swollen mitochondria. These organelles also showed other signs of degeneration: in the mitochondrial matrix electron-lucent and condensed areas were seen, the mitochondrial granules were lost and the inner membranes fragmented. In most cases the outer membrane of the mitochondria remained intact (Fig. 12). The basilar infoldings of the cells frag-

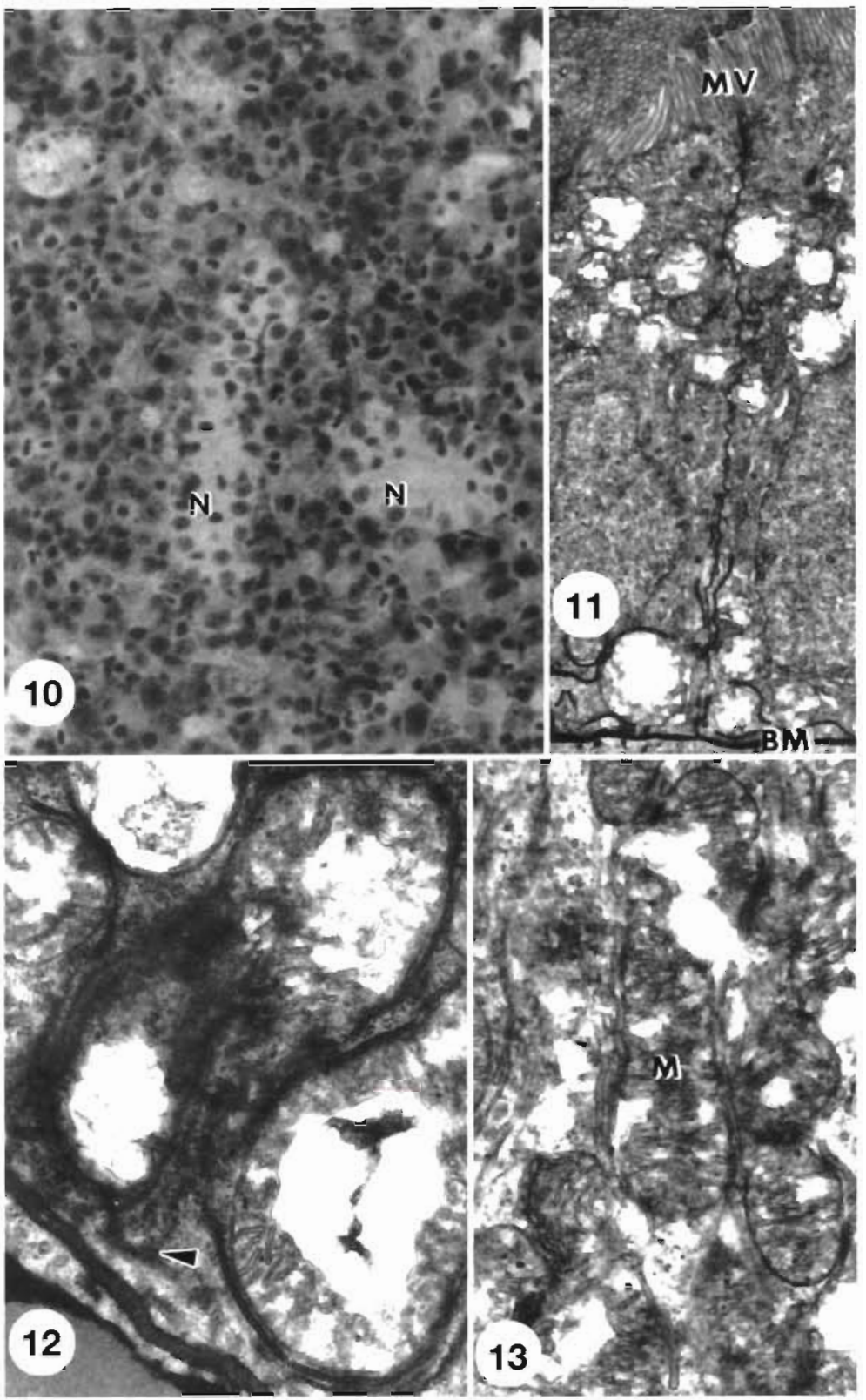

Figs. 10 to 13. Renal tubule cells from the kidney of carp $21 \mathrm{~d}$ PI with Trypanoplasma borreli. Fig. 10. The proliferation of the interstitial tissue of the kidney has progressed massively and kidney tubules (N) atrophied (light micrograph, $\times 380$ ). Fig. 11. Proximal tubule cell: the cell appears to be filled with holes, which resulted from swollen mitochondria. BM: basal lamina, MV: microvilli (TEM, ×6500). Fig. 12. Proximal tubule cell: the basilar infoldings (arrowhead) are fragmented, the mitochondria are swollen, in their matrix condensed and electron-lucent areas are seen. Mitochondrial granules are lost. In most cases the outer membrane of the mitochondria remained intact $(T E M, \times 25600)$. Fig. 13. Distal tubule cell: the mitochondria $(\mathrm{M})$ are swollen, the outer membrane ruptured and the matrix edematized (TEM, $\times 25600$ )

mented, the fragments were filled with electron-dense material and their membrane disbanded (Fig. 12). Other organelles of the cells from the proximal tubule, 
like the nuclear membrane, the brush border and the junctional complex, remained unchanged even at this stage of the parasitaemia.

In the distal renal tubule the majority of the cells also appeared to be filled with holes, which indicated mitochondrial changes (Fig. 13). Their mitochondria had lost the granules, wide areas of the mitochondrial matrix had a pale appearence, and the inner and outer membranes were ruptured (Fig 13). In the cells from the distal tubule the basilar invaginations were hardly visible (Fig. 13). In some of the cells the nuclear membrane disintegrated, but the apical protrusions and the junctional complexes of the cells remained unchanged.

The renal corpuscles did not show any obvious changes throughout this study.

At Day 21 PI, when high numbers of trypanoplasms were present in the circuclating blood, massive accumulations of trypanoplasms were seen in blood vessels and in the interstitial tissue of the kidney.

\section{DISCUSSION}

In susceptible carp and goldfish the infection with Trypanoplasma borreli induced a prominent proliferation of the interstitial renal tissue, which resulted in a tubular necrosis (Lom \& Dykova 1992, Bunnajirakul et al. 2000). The detrimental effect of the space-demanding proliferation process on the excretory tissue of the kidney could be noted very early during the development of the parasite. At Day 7 PI, we alr eady observed mitochondrial swellings and a fragmentation of the basilar invaginations in tubular epithelium cells. With the development of the parasitaemia on Days 14 and $21 \mathrm{PI}$, the deterioration of mitochondria and basilar invaginations progressed, whilst other structures of the cell like the endoplasmic reticulum and junctional complexes remained unchanged. The mitochondrial alterations reached an extent which suggested a complete loss of function, for instance in osmotic or ion regulation. Cells of the distal segment of the nephron appeared to be very vulnerable to the changes induced during the development of the parasitaemia. In these cells swollen or degenerating mitochondria and fragmented basilar invaginations were seen earlier and developed more rapidly than in cells from the proximal tubule.

In freshwater teleosts the kidney is mainly involved in osmotic and ion regulation. As a result of the large concentration gradient of ions between the surrounding fresh water and the body fluid, they constantly have to fight against an osmotic influx of water across the branchial epithelium and other body surfaces. This is met by the production of large quantities of dilute urine and by active uptake of ions from the water at the gill epithelium (Evans 1993). In the renal tubule, $\mathrm{NaCl}$ is secreted into the urine by the proximal tubule epithelium. This draws water into the lumen osmotically and thus presumably aids the formation of urine (Evans 1993). $\mathrm{NaCl}$ is conserved by reabsorption in the distal tubule, resulting in an ion concentration of about 20 mOsm $\mathrm{l}^{-1}$, less than $10 \%$ of the plasma concentration (Evans 1979). It is most likely that due to the destruction of the mitochondria and the fragmentation of the basilar invaginations in $T$. borreli-infected carp the osmoregulatory functions of the nephron were disturbed. As a result the infected carp most likely had to cope with a challenge of osmoregulatory processes, which might be indicated by the ascitis observed in carp with high $T$, borreli parasitaemias.

Tubular necrosis occurred in fishes as a result of pathological processes of the interstitial tissue and the vasculation as observed in the present study or, for instance, in rainbow trout Oncorhynchus mykiss suffering from proliferative kidney disease (Hedrick et al. 1993). In affected trout, the renal interstitial tissue increased rapidly due to an accumulation of macrophages (Clifton-Hadley et al. 1987, MacConnell et al. 1989, Hoffmann \& El-Matbouli 1994) and a proliferation of lymphocytes (Chilmonczyk \& Monge 1999). Concurrently with the proliferation of the interstitial tissue, in the kidney of affected rainbow trout a necrosis of renal tubules was observed (Kent \& Hedrick 1986, Clifton-Hadley et al. 1987, MacConnell et al. 1989, Hedrick et al. 1993). Physiological studies showed that in these rainbow trout the regulation of the ion balance and the osmotic pressure was impaired: the serum protein levels dropped (Hoffmann \& Lommel $1984)$ and the level of the divalent cations calicum and magnesium was elevated (Foot \& Hedrick 1990).

In teleosts histo- and cytopathological alterations of the kidney were observed in the context of many infections or diseases (Ferguson 1989), but their effect on the piscine organism seems to be much less detrimental than in homoiothermic vertebrates (Thomson 1978), most likely because in teleosts many excretory functions of the mammalian or avian kidney are carried out by other tissues. Nitrogenic waste for instance is mainly excreted across the branchial epithelium (Evans 1993). In summary, the anaemia experienced by carp with a clinical Trypanoplasma borreli infection is considered to be the most significant feature of disease (Lom \& Dykova 1992, Bunnajirakul et al. 2000). The degeneration of nephrons should be considered a factor that contributes to the severity of the disease.

In this study, we used hybrid F1 carp from an isogenic strain which were highly susceptible to the parasite. In former experiments we inoculated similar numbers of Trypanoplasma borreli from the same stock into 
outbred carp (Steinhagen et al. 1989), which developed much lower levels of parasitaemia and did not show any signs of pathology. Major differences in susceptibility of carp to $T$. borreli infections were also observed by Wiegertjes et al. (1995), who found that outbred carp responded with a production of specific antibodies, but highly susceptible carp did not. Thus the authors assumed that there might be a relationship between susceptibility to $T$. borreli infection and specific antibody production. A passive transfer of immune plasma, however, resulted only in partial protection of susceptible carp (Wiegertjes et al. 1995). Therefore, it still remains unclear how outbred carp encounter a $T$. borreli infection.

Acknowledgements. Mr S. H. Leenstra and Dr G. Wiegertjes, Wagenigen Agricultural University, The Netherlands, kindly provided fertilized carp eggs. We are grateful to Mrs K. Franke and Mrs K. Rohn, Hannover, for preparing excellent thin sections. This study was financially supported, in part, by a DFG grant to D.S.

\section{LITERATURE CITED}

Bunnajirakul S, Steinhagen D, Hetzel U, Körting W, Drommer W (2000) A study of sequential histopathology of Trypanoplasma borreli (Protozoa: Kinetoplastida) in susceptible common carp Cyprinus carpio. Dis Aquat Org 39:221-229

Chilmonczyk S, Monge D (1999) Flow cytometry as a tool for assessment of the fish cellular immune responses to pathogens. Fish Shellfish Immunol 9:319-333

Clifton-Hadley RS, Bucke D, Richards RH (1987) A study of the sequential clinical and pathological changes during proliferative kidney disease in rainbow trout, Salmo gairdneri Richardson. J Fish Dis 10:335-352

Evans DH (1979) Fish. In: Maloiy GM (ed) Comparative physiology of osmoregulation in animals. Academic Press, Orlando, p 305

Evans DH (1993) Osmotic and ionic regulation. In: Evans DH (ed) The physiology of fishes. CRC Press, Boca Raton, FL, p 315-341

Ferguson HW (1989) Systemic pathology of fish. Iowa State University Press, Ames, IA

Editorial responsibility: Otto Kinne (Managing Editor), Oldendorf/Luhe, Germany
Foot JS, Hedrick RP (1990) Blood parameters and immune status of rainbow trout with proliferative kidney disease. $\mathrm{J}$ Aquat Anim Health 2:141-148

Hayat MA (1989) Principles and techniques of electron microscopy, 3rd edn. Macmillan Press, Houndsmills

Hedrick RP, MacConnell E, de Kinkelin P (1.993) Proliferative kidney disease of salmonid fish. Annu Rev Fish Disease 3: $277-290$

Hoffmann RW, El-Matbouli M (1994) Proliferative kidney disease (PKD) as an important myxosporean infection in salmonid fish. In: Pike AW, Lewis JW (eds) Parasitic diseases of fish. Samara Publishing Ltd, Tresaith, p 3-15

Hoffmann R, Lommel R (1984) Haematological studies in proliferative kidney disease of rainbow trout, Salmo gairdneri Richardson. J Fish Dis 7:323-326

Kent ML, Hedrick RP (1986) Development of the PKX myxosporean in rainbow trout Salmo gairdneri. Dis Aquat Org $1: 169-182$

Keysselitz G (1906) Generations- und Wirtswechsel von Trypanoplasma borreli Laveran und Mesnil. Arch Protistenkd 8:1-71

Lom J (1979) Biology of the trypanosomes and trypanoplasms of fish. In: Lumsden WHR, Evans DA (eds) Biology of the Kinetoplastida. Academic Press, London, p 269-337

Lom J, Dykova I (1992) Protozoan parasites of fishes. Developments in aquaculture and fisheries science, Vol 26 Elsevier, Amsterdam

Lom J, Dykova I, Machackova B (1986) Experimental evidence of pathogenicity of Trypanoplasma borreli and Trypanosoma danilewskyi for carp fingerlings. Bull Eur Assoc Fish Pathol 6:87-88

MacConnell E, Smith CE, Hedrick RP, Speer CA (1989) Cellular inflammatory response of rainbow trout to the protozoan parasite that causes proliferative kidney disease. J Aquat Anim Health 1:108-118

Romeis B (1989) Mikroskopische Technik, 17th edn. In: Böck $P$ (ed) Urban \& Schwarzenberg, Munich

Steinhagen D, Kruse P, Körting W (1989) The parasitemia of cloned Trypanoplasma borreli Laveran and Mesnil, 1901 in laboratory-infected common carp (Cyprinus carpio) J Parasitol 75:685-689

Thomson RG (1978) General veterinay pathology. Saunders, Philadelphia

Wiegertjes GF, Groeneveld A, van Muiswinkel WB (1995) Genetic variation in susceptibility to Trypanoplasma borreli infection in common carp (Cyprinus carpio L.). Vet Immunol Immunopathol 47:153-161

Submitted: November 15, 1999; Accepted: January 25, 2000 Proofs received from author(s): March 17, 2000 